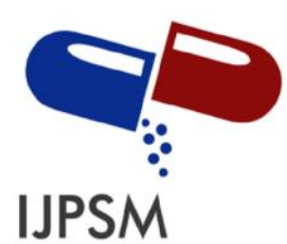

Fabricio Paul Gamarra Castillo et al, Int. Journal of Pharmaceutical Sciences and Medicine (IJPSM),

Pharma Middle East Virtual Congress (Dec 07-08, 2020)

www.pharma-middleeast.plenareno.com

ISSN: 2519-9889

Impact Factor: 3.426

\title{
Nociceptive Evaluation of the Lyophilized Extract of Lupinus mutabilis sweet (Tarwi) in Experimental Animals
}

\section{Fabricio Paul Gamarra Castillo ${ }^{1, a}$, Alberto Salazar Granada ${ }^{\text {b }}$, Jorge Martinez Herrera ${ }^{c}$ and Ricardo Borges Jurado ${ }^{d}$}

1 Universidad de San Martin de Porres, Facultad de Medicina Humana CIMTFAR, Instituto de Investigación, Lima, Perú.

a Médico, Magister en Ciencias Básicas, Mención en Farmacología, Docente Investigador.

b Médico, Doctor en Medicina, Presidente de la SOPFARTEX.

c Químico, Doctor en Alimentos, Instituto Nacional de Investigaciones Forestales, Agrícolas y Pecuarias (INIFAP) Campo Experimental Huimanguillo, Huimanguillo, Tabasco, México.

d Médico, Doctor en Medicina, Farmacólogo, Universidad de la Laguna Tenerife, España.

DOI: 10.47760/ijpsm.2020.v05i12.002

\begin{abstract}
Objective: To determine by means of the plantar test (hargreaves method) in albino rats the nociceptive effect of the lyophilized extract of Lupinus mutabilis sweet (Tarwi).

Materials and Methods: Experimental research using a method of measuring thermal nociception in cutaneous hyperalgesia in animal models, taking into account the IASP Guide and ethical management regarding experimental pain in animals. The nociceptive effects of the lyophilized extract of Lupinus mutabilis Sweet (Tarwi) compared to Placebo and Morphine were evaluated, observing the paw withdrawal time using a plantar test kit in albino rats.

Results: The response of the thermal heat produced in planting tests in the albino rats treated with the lyophilized extract of Lupinus mutabilis Sweet (Tarwi) administered at the rate of 1000 doses. 1250, 1500 and $1800 \mathrm{mg} / \mathrm{Kg}$, regarding the nociceptive effect in the times of reaction (TR) in the evaluated time 15, 30 and 60 min was evaluated as having the Tukey pairing test.
\end{abstract}

Conclusion: Statistical significance and effect were found in the Plantar Test in albino rats to assess the antinociceptive effect.

Keywords: Plantar test, Lupinus mutabilis, nociception, Hargreaves method. 